The Waste Market 


\section{The Waste Market}

\section{Institutional Developments in Europe}

Edited by

E. Dijkgraaf

SEOR-ECRi, Erasmus University Rotterdam, Rotterdam, The Netherlands

and

R.H.J.M. Gradus

Faculty of Economics and Business Administration, VU University Amsterdam, Amsterdam, The Netherlands 
E. Dijkgraaf

SEOR-ECRi

Erasmus University Rotterdam

P.O. Box 1738

3000 DR Rotterdam

The Netherlands
R.H.J.M. Gradus

Faculty of Economics and Business Administration

VU University Amsterdam

De Boelelaan 1105

1081 HV Amsterdam

The Netherlands

ISBN: 978-1-4020-8710-3

e-ISBN: 978-1-4020-8711-0

Library of Congress Control Number: 2008930933

(c) 2008 Springer Science+Business Media B.V.

No part of this work may be reproduced, stored in a retrieval system, or transmitted

in any form or by any means, electronic, mechanical, photocopying, microfilming, recording

or otherwise, without written permission from the Publisher, with the exception

of any material supplied specifically for the purpose of being entered

and executed on a computer system, for exclusive use by the purchaser of the work.

Cover image (c) 2008 JupiterImages Corporation

Printed on acid-free paper

$\begin{array}{llllllllll}9 & 8 & 7 & 6 & 5 & 4 & 3 & 2 & 1\end{array}$

springer.com 


\section{Contents}

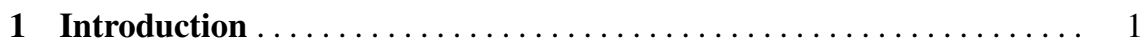

E. Dijkgraaf and R.H.J.M. Gradus

2 Cost Savings of Contracting Out Refuse Collection in The Netherlands 9 E. Dijkgraaf and R.H.J.M. Gradus

3 Contracting Out Refuse Collection in The Netherlands

E. Dijkgraaf, R.H.J.M. Gradus and B. Melenberg

4 Contracting Out in Sweden: Ownership and Production Costs

H. Ohlsson

5 Does Public Ownership Impair Efficiency in Norwegian Refuse

Collection? .................................... 67

R.J. Sørensen

6 Refuse Collection in Spain: Privatization, Intermunicipal

Cooperation, and Concentration $\ldots \ldots \ldots \ldots \ldots \ldots \ldots \ldots \ldots \ldots$

Germà Bel

7 How to Get Increasing Competition

in the Dutch Refuse Collection Market?

E. Dijkgraaf and R.H.J.M. Gradus

8 Dutch Cost Savings in Unit-Based Pricing of Household Waste

E. Dijkgraaf and R.H.J.M. Gradus

9 Assessing Instruments for Mixed Household Solid Waste Collection

Services in Flanders ............................... 131

X. Gellynck and P. Verhelst

10 Final Comments and Future Research

E. Dijkgraaf and R.H.J.M. Gradus

Index 


\section{Contributors}

\section{Germà Bel}

Universitat de Barcelona and ppre-IREA, Dep. de Política Econòmica,

Av. Diagonal, 69008034 Barcelona, Spain, e-mail: gbel@ub.edu

E. Dijkgraaf

SEOR-ECRi, Erasmus University Rotterdam, P.O. Box 1738,

3000 DR Rotterdam, The Netherlands, e-mail: dijkgraaf@few.eur.nl

X. Gellynck

Department of Agricultural Economics, Ghent University, Coupure links 653,

B-9000 Ghent, e-mail: xavier.gellynck@UGent.be

R.H.J.M. Gradus

Faculty of Economics and Business Administration, VU University Amsterdam, De

Boelelaan 1105, 1081 HV Amsterdam, The Netherlands, e-mail: rgradus@ @eweb.vu.nl

B. Melenberg

Tilburg University, K 615, P.O. Box 90153, 5000 LE Tilburg, The Netherlands, e-mail: b.melenberg@uvt.nl

H. Ohlsson

Department of Economics, Uppsala University, P.O. Box 513, SE-751 20 Uppsala, Sweden, e-mail: henry.ohlsson@nek.uu.se

\section{R.J. Sørensen}

Department of Public Governance, Norwegian School of Management, Nydalsveien 37, 0484 Oslo, Norway, e-mail: rune.sorensen@bi.no

P. Verhelst

Department of Agricultural Economics, Ghent University, Coupure links 653, B-9000 Ghent, e-mail: Pieter.Verhelst@UGent.be 